\title{
Digestive utilization of quebracho-treated soya bean meals in sheep
}

\author{
P. FRUTOS*, G. HERVÁS, F. J. GIRÁldEZ, M. FERNÁNDEZ And A. R. MANTECÓN \\ Estación Agrícola Experimental, CSIC, Apdo 788, 24080-León, Spain
}

(Revised MS received 21 May 1999)

\begin{abstract}
SUMMAR Y
A study on the use of quebracho tannins as chemical additives was carried out at the Spanish Council for Scientific Research, León, Spain during 1998 by conducting two experiments. In the first experiment, three ruminally cannulated ewes were used to determine in situ degradability of soya bean meals (SBM) treated with different doses of quebracho tannin. Samples were prepared by spraying $100 \mathrm{~g}$ SBM with $100 \mathrm{ml}$ distilled water containing $0,1,5,10,15$ or $25 \mathrm{~g}$ of commercial quebracho powder $\left(\mathrm{S}_{0}, \mathrm{~S}_{\mathrm{Q} 1}, \mathrm{~S}_{\mathrm{Q} 2}, \mathrm{~S}_{\mathrm{Q} 3}, \mathrm{~S}_{\mathrm{Q} 4}\right.$ and $\mathrm{S}_{\mathrm{Q} 5}$, respectively). Intestinal digestibility of non-degradable protein was estimated in vitro. The rapidly degradable protein fraction of all quebracho treated soya bean meals was different $(P<0 \cdot 05)$ from the non-treated SBM $\left(\mathrm{S}_{0}: 0 \cdot 154\right)$, with values ranging from 0.032 to 0.133 . $\mathrm{S}_{\mathrm{Q} 4}$ and $\mathrm{S}_{\mathrm{Q} 5}$ showed lower fractional rates of degradation of the protein than $\mathrm{S}_{0}(0 \cdot 042$ and 0.046 v. 0.082, respectively). By contrast, in vitro digestibility of the non-degradable protein was not significantly affected by the treatments imposed, with the exception of treatment with the highest dose of quebracho tannin in which intestinal digestion was reduced $\left(0.939 v .0 .826\right.$ for $\mathrm{S}_{0}$ and $\mathrm{S}_{Q_{5}}$, respectively. $P<0.05)$. In the second experiment, ten ruminally cannulated ewes were used to examine the effect of a daily dosing of quebracho tannin into the rumen on the degradation of the quebrachotreated SBM. Long-term dosing of quebracho tannin did not increase the ability of the rumen microbes to degrade tannin treated SBM. It was therefore concluded that quebracho tannins could be used as chemical additives for improving the digestive utilization of protein-rich feeds in sheep.
\end{abstract}

\section{INTRODUCTION}

Tannins are a complex group of polyphenolic compounds occurring in a wide range of plants species commonly consumed by ruminants (McLeod 1974). Condensed tannins (CT) are probably the most studied secondary metabolites in animal nutrition because they are extremely widespread and have been reported to have both beneficial and detrimental effects. They have been suggested as possible chemical additives for decreasing ruminal degradation of protein (Schwab 1995) due to their ability to form tannin-protein complexes which are stable over a wide range of $\mathrm{pH}$, but which dissociate at $\mathrm{pH}<3.5$ and $>8 \cdot 5$. Barry \& Manley (1984) observed that, after passing through the rumen, proteins protected from microbial degradation were released in the abomasum, enabling absorption of amino acids from the small intestine. However, some other authors (Griffiths 1979; Horigome et al. 1988; Silanikove et al. 1994) have reported an anti-nutritional effect of tannins,

* To whom all correspondence should be addressed. Email: p.frutos@eae.csic.es which they attributed to depression of digestive tract enzyme activity. Further research is needed therefore if these compounds are to be used as chemical additives for improving the digestive utilization of protein-rich feeds.

Ruminant herbivores have evolved different means of overcoming plant chemical defences. There are several examples where the rumen has been shown to represent an important site of biotransformation and detoxification of plant secondary compounds (Cheeke \& Palo 1995; Dominguez-Bello 1996). In certain circumstances, it has been shown that a gradual increase in the intake of these compounds by the ruminant increases the animals' tolerance to these toxin-containing plants (Quirk et al. 1988; Duncan et al. 1997).

Although some authors have found evidence for losses of condensed tannin from the rumen possibly due to bacterial degradation (Perez-Maldonado \& Norton 1996), others suggest virtually no degradation (Terrill et al. 1994; Makkar et al. 1995), and there is still some debate on this issue. If it were true that rumen micro-organisms are able to adapt to and degrade condensed tannins, this might invalidate the 
use of these compounds as chemical additives to protect dietary protein from microbial degradation.

The two experiments reported here were carried out to study the potential use of condensed tannins as additives for improving the digestive utilization of feed protein. In Experiment 1, the influence of quebracho tannins on ruminal degradation and postruminal digestion of quebracho-treated soya bean meals (SBM) was measured. In Experiment 2 the effect of a long-term dosing of quebracho tannin into the rumen of sheep on the ruminal degradation of quebracho-treated SBM was examined.

\section{MATERIAL AND METHODS}

Experiment 1

\section{Animals and diet}

Three individually penned Merino ewes (mean live weight $48.6 \mathrm{~kg}$; S.E. $2 \cdot 11$ ), fitted with ruminal cannulae of $35 \mathrm{~mm}$ internal diameter, were used in this experiment. The animals were offered grass hay (dry matter $(\mathrm{DM})=915 \mathrm{~g} / \mathrm{kg}$; crude protein $(\mathrm{CP})=85$ $\mathrm{g} / \mathrm{kg} \mathrm{DM}$; neutral detergent fibre $(\mathrm{NDF})=610 \mathrm{~g} / \mathrm{kg}$ $\mathrm{DM}$ ) in two equal meals (at 09.30 and $18.00 \mathrm{~h}$ ) at 1.2 times their estimated maintenance requirements for energy (AFRC 1993), for 10 days prior to commencing the experiment and throughout the experimental period. Clean water and vitamin-mineral blocks were always available.

\section{Procedures}

Soya bean meal treatments. Six samples of $100 \mathrm{~g}$ $\mathrm{SBM}(\mathrm{DM}=937 \mathrm{~g} / \mathrm{kg} ; \mathrm{CP}=471 \mathrm{~g} / \mathrm{kg} \mathrm{DM}$; ash = $123 \mathrm{~g} / \mathrm{kg} \mathrm{DM}$ ) were ground using a hammer-mill fitted with a $2 \mathrm{~mm}$ screen and sprayed with $100 \mathrm{ml}$ distilled water containing $0,1,5,10,15$ or $25 \mathrm{~g}$ of quebracho powder (Q; Roy Wilson Dickson Ltd., England). These treated soya bean meals were called $\mathrm{S}_{0}$ (control), $\mathrm{S}_{\mathrm{Q} 1}, \mathrm{~S}_{\mathrm{Q} 2}, \mathrm{~S}_{\mathrm{Q} 3}, \mathrm{~S}_{\mathrm{Q} 4}$ and $\mathrm{S}_{\mathrm{Q} 5}$, respectively. Samples were dried at $40-45^{\circ} \mathrm{C}$ for $24 \mathrm{~h}$ and ground again to remove lumps.

Rumen degradation. Rumen degradation was measured by in situ methods. Nylon bags $(12.0 \times 8.5 \mathrm{~cm}$; Maissa $^{\mathbb{R}}$, Spain) made of filter cloth with an approximate pore size of $45 \mu \mathrm{m}$ diameter were used. Four grams (DM) of each SBM were incubated in the rumen of each of the three ewes for 3, 6, 12, 24, 48 and $72 \mathrm{~h}$. Six bags, each containing one of the six treated meals were introduced together into the rumen of each sheep before the morning feed. After removal from the rumen (all six at once) the bags were washed with cold water in a commercial washing machine. They were then dried in a forced-air oven at $45^{\circ} \mathrm{C}$ and weighed to determine DM losses. $\mathrm{N}$ concentration in the residues was measured to determine $\mathrm{N}$ losses. Zero-time losses were estimated by washing two bags per sample with the same washing programme used to wash the bags after the incubations.

Intestinal digestion. Intestinal digestion of protein in the treated SBM was determined following the three-step in vitro procedure developed by Calsamiglia \& Stern (1995). A nylon bag residue sample (containing $15 \mathrm{mg}$ of nitrogen), after a ruminal incubation for $16 \mathrm{~h}$, was incubated for $1 \mathrm{~h}$ in $10 \mathrm{ml}$ of a $0 \cdot 1 \mathrm{M} \mathrm{HCl}$ solution containing $1 \mathrm{~g} / \mathrm{l}$ of pepsin (SIGMA, P-7012). After incubation, $\mathrm{pH}$ was then neutralized with $0.5 \mathrm{ml}$ of $1 \mathrm{M} \mathrm{NaOH}$, and $13.5 \mathrm{ml}$ of a $\mathrm{pH} 7 \cdot 80 \cdot 15 \mathrm{M}$ phosphate buffer containing $3 \mathrm{~g} / 1$ of pancreatin (SIGMA, P7045) were added to the solution and incubated at $38^{\circ} \mathrm{C}$. After a $24-\mathrm{h}$ incubation, $3 \mathrm{ml}$ of a trichloroacetic acid solution ( $1 \mathrm{~g} \mathrm{TCA} / \mathrm{ml}$ distilled water) were added to precipitate undigested proteins. After 15 minutes, samples were centrifuged at $10000 \mathrm{~g}$ for $15 \mathrm{~min}$ and the supernatant analysed for soluble $\mathrm{N}$ by the Kjeldahl method (AOAC 1990).

\section{Experiment 2}

Animals and diet

Ten individually penned Merino ewes (mean live weight $54.6 \mathrm{~kg}$; S.E. 2.87), fitted with ruminal cannulae of $35 \mathrm{~mm}$ internal diameter, were used. Animals were offered a diet of dehydrated alfalfa hay $(\mathrm{DM}=$ $926 \mathrm{~g} / \mathrm{kg} ; \quad \mathrm{CP}=151 \mathrm{~g} / \mathrm{kg} \quad \mathrm{DM} ; \quad \mathrm{NDF}=438 \mathrm{~g} / \mathrm{kg}$ $\mathrm{DM}$ ), split into two equal meals (fed at 09.30 and $18.00 \mathrm{~h}$ ), at 1.2 times their estimated maintenance requirements for energy, throughout the experimental period. Clean water and vitamin-mineral blocks were always available.

\section{Procedures}

Quebracho dosing. Quebracho tannin powder (Roy Wilson Dickson Ltd., England) was dissolved in $200 \mathrm{ml}$ of distilled water containing $0.8 \mathrm{ml}$ of methanol/1, and dosed into the rumen of the ewes using a plastic syringe. The dose rates of quebracho were as follows: $0.75 \mathrm{~g} / \mathrm{kg} \mathrm{LW} /$ day to five animals ('dosed') and $0.0 \mathrm{~g} / \mathrm{kg} \mathrm{LW} /$ day to the remaining five ewes ('control'). All the animals received the solution once daily, immediately before the morning feed, for two months.

Soya bean meal treatments. Two samples of $100 \mathrm{~g}$ $\mathrm{SBM}(\mathrm{DM}=926 \mathrm{~g} / \mathrm{kg} ; \mathrm{CP}=432 \mathrm{~g} / \mathrm{kg} \mathrm{DM}$; ash = $70 \mathrm{~g} / \mathrm{kg} \mathrm{DM}$ ) ground to pass a $2 \mathrm{~mm}$ screen were sprayed with $100 \mathrm{ml}$ distilled water containing either 0 or $15 \mathrm{~g}$ of quebracho powder. These treated soya bean meals were called $\mathrm{S}_{0}$ and $\mathrm{S}_{\mathrm{Q}}$, respectively. They were dried at $40{ }^{\circ} \mathrm{C}$ for $24 \mathrm{~h}$ and ground again to remove lumps.

In situ studies. Four grams of each of the two soya bean meals $\left(\mathrm{S}_{0}\right.$ and $\left.\mathrm{S}_{\mathrm{Q}}\right)$ were incubated in the rumen of each of the ten ewes for $12 \mathrm{~h}$, following the 
procedures previously described in Experiment 1, on days 30 and 60 of quebracho dosing.

Necropsy. The day after the last rumen incubations, the five 'quebracho dosed' ewes were euthanased with an intravenous injection of sodium pentabarbitone and necropsied. Major organs were assessed for macroscopic lesions and then fixed in $10 \%$ buffered formalin. Histological examination was carried out basically on the liver, kidneys and gastrointestinal tract.

\section{Chemical analysis}

In both experiments, procedures described by AOAC (1990) were used to determine DM, ash and Kjeldahl nitrogen (N). NDF was determined by the method of Goering \& Van Soest (1970).

\section{Calculations and statistical analysis}

\section{Experiment 1}

Dry matter and nitrogen disappearances were fitted to the model described by Ørskov \& McDonald (1979) $\left[d=a+b\left(1-\mathrm{e}^{(-c t)}\right)\right]$, where $d$ represents the loss from the bag after $t$ hours, $a$ the rapidly degradable fraction, $b$ the slowly degradable fraction and $c$ the rate of degradation of fraction $b$. The equation was fitted to in situ degradation profiles using the Marquardt method for interactive, nonlinear, least square estimation using the SAS package (SAS 1989).

Degradability $(\mathrm{Dg})$ was estimated by using the parameters $a, b$ and $c$ and a ruminal passage rate $\left(K_{p}\right)$ value of 0.08 , according to the equation described by Ørskov \& McDonald (1979): [Dg=a+(bc/(c+K $\left.\left.\left.K_{p}\right)\right)\right]$.

Data relating to DM and $\mathrm{N}$ disappearances were analysed using analysis of variance with a factorial treatment structure ( 6 soya bean meals $\times 6$ incubation times). The variance components between experimental treatments, and between animals, were estimated and the residual variance was obtained by subtracting both from the total. The treatment variance was split into components attributable to main factors and their interaction. Comparisons among soya bean meals for the rumen degradation characteristics and the degradability were made using analysis of variance with the animal effect as a block. The LSD test was used to assess the significance of differences between treatment means where the overall treatment effect was significant $(P<0 \cdot 05)$.

\section{Experiment 2}

The second experiment was analysed using a splitsplit-plot analysis of variance, with dosing treatment as the main plot, soya bean meals $\left(\mathrm{S}_{0}\right.$ and $\left.\mathrm{S}_{\mathrm{Q}}\right)$ as subplot and day (30 and 60) as repeated observations (sub-subplot). Animals were nested within dosing treatment and used as the error term to contrast the dosing treatment effect. To assess the effect of the soya bean meals, its interaction with the animal was used as the subplot error.

All data (Experiments 1 and 2) were analysed using the procedures of the Statistical Analysis Systems (SAS 1989).

\section{RESULTS}

Digestive utilization of quebracho-treated soya bean meals

Dry matter and nitrogen disappearances from the bags incubated in the rumen for the control and quebracho-treated soya bean meals can be observed in Figs 1 and 2. Quebracho treatment of soya bean meals decreased DM and $\mathrm{N}$ disappearance from bags. The greatest effects were found in the meals treated with the highest doses of quebracho $\left(\mathrm{S}_{\mathrm{Q} 4}\right.$ and $\left.\mathrm{S}_{\mathrm{Q5}}\right)$ and up to $24 \mathrm{~h}$ incubations.

Ruminal degradation of the different soya bean meals was reasonably described $\left(R^{2}=0.99 \pm 0.001\right)$ by the exponential equation defined by Ørskov \& McDonald (1979) and a large deviation from the adjusted curves was not observed $(\mathrm{RSD}=0.034 \pm$ 0.0022). The in sacco $\mathrm{DM}$ and $\mathrm{N}$ degradation parameters ( $a, b$ and $c$ values) of the control and treated soya bean meals are presented in Table 1 .

There were no significant differences $(P>0.05)$ between soya bean meals in the potential degradability $(a+b)$. By contrast, treatment with quebracho significantly affected both the rapidly degradable fraction (a) and the rate of degradation (c), this effect depending on the dose of tannins used to treat the meals.

The rapidly degradable nitrogen fraction of all the treated soya bean meals was lower than the control one $\left(S_{0}: 0 \cdot 154\right)$, with values ranging from 0.032 to $0 \cdot 132$. The rapidly degradable DM fraction of treated soya bean meals was similar to the rapidly degradable DM fraction of the control, with the exception of the $\mathrm{S}_{\mathrm{Q} 3}(P<0 \cdot 05)$.

The two soya bean meals treated with the highest doses of quebracho $\left(\mathrm{S}_{Q 4}\right.$ and $\left.\mathrm{S}_{Q 5}\right)$ showed lower rates of degradation than the control $\left(\mathrm{S}_{0}\right)$, both for $\mathrm{DM}$ and $\mathrm{N}$. Treatments with the other three doses of quebracho (those of meals $\mathrm{S}_{\mathrm{Q} 1}, \mathrm{~S}_{\mathrm{Q} 2}$ and $\mathrm{S}_{\mathrm{Q} 3}$ ) did not affect the rate of degradation $(P>0.05)$.

In agreement with these results, degradability of the soya bean meals was also affected by the quebracho treatment (see Table 1). In relation to the DM degradability, only meals $\mathrm{S}_{\mathrm{Q} 4}$ and $\mathrm{S}_{\mathrm{Q} 5}$ showed significantly lower values than the control. In relation to the $\mathrm{N}$ degradability, the significant decrease caused by the tannin treatment was observed on $\mathrm{S}_{\mathrm{Q} 3}, \mathrm{~S}_{\mathrm{Q} 4}$ and $\mathrm{S}_{\mathrm{Q} 5}$.

Quebracho treatment of soya bean meals did not significantly affect intestinal digestion of non-degradable protein in $\mathrm{S}_{\mathrm{Q} 1}, \mathrm{~S}_{\mathrm{Q} 2}, \mathrm{~S}_{\mathrm{Q3}}$ and $\mathrm{S}_{\mathrm{Q} 4}$. However, the treatment with the highest dose of quebracho powder 


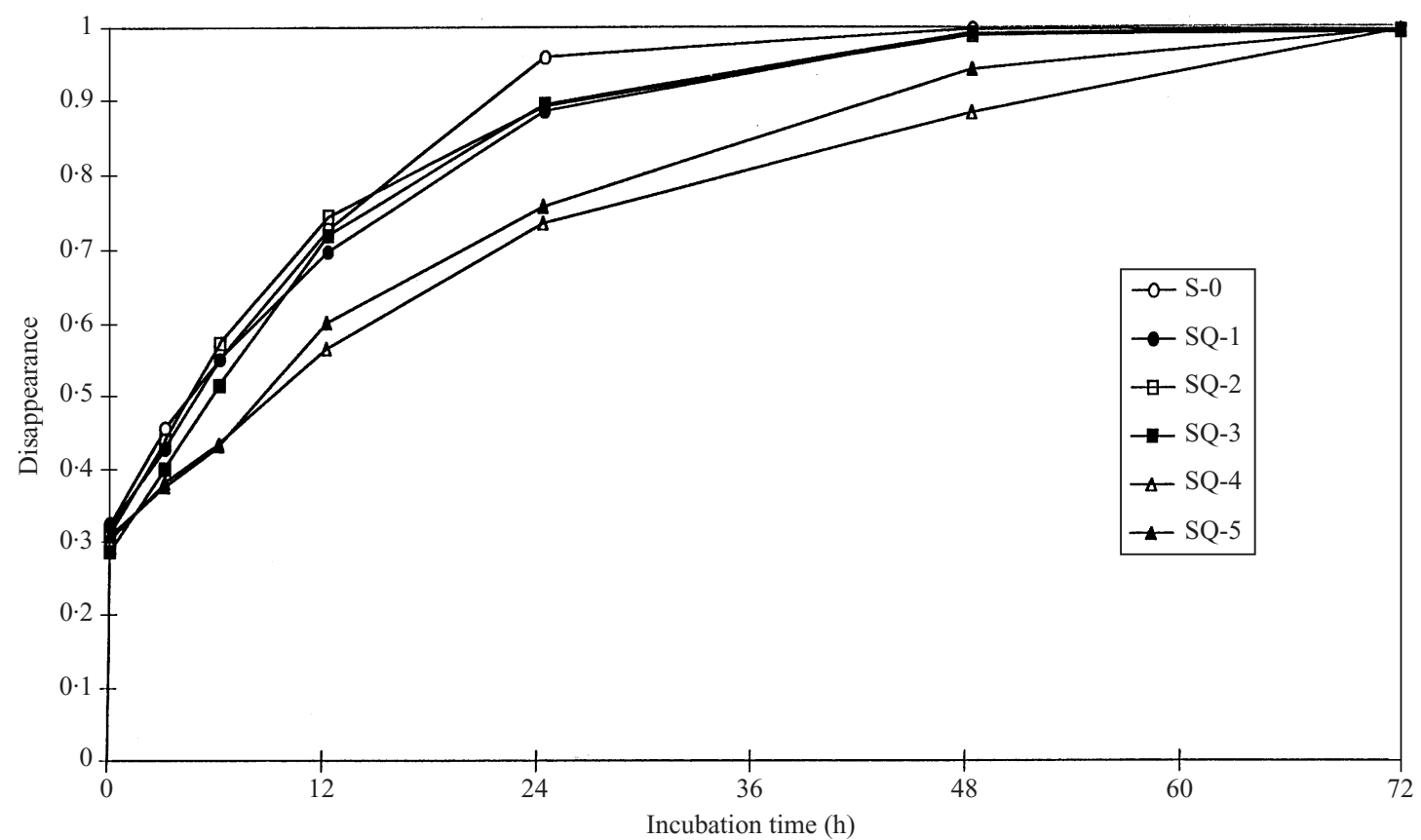

Fig. 1. In situ dry matter disappearance curves of the control $\left(\mathrm{S}_{0}\right)$ and quebracho-treated soya bean meals $\left(\mathrm{S}_{\mathrm{Q} 1}, \mathrm{~S}_{\mathrm{Q} 2}, \mathrm{~S}_{\mathrm{Q} 3}\right.$, $\mathrm{S}_{\mathrm{Q} 4}$ and $\mathrm{S}_{\mathrm{Q} 5}$ ). S.E. for the interaction between incubation time and quebracho tannin treatment $=0 \cdot 0226$ (D.F. $=70$ ).

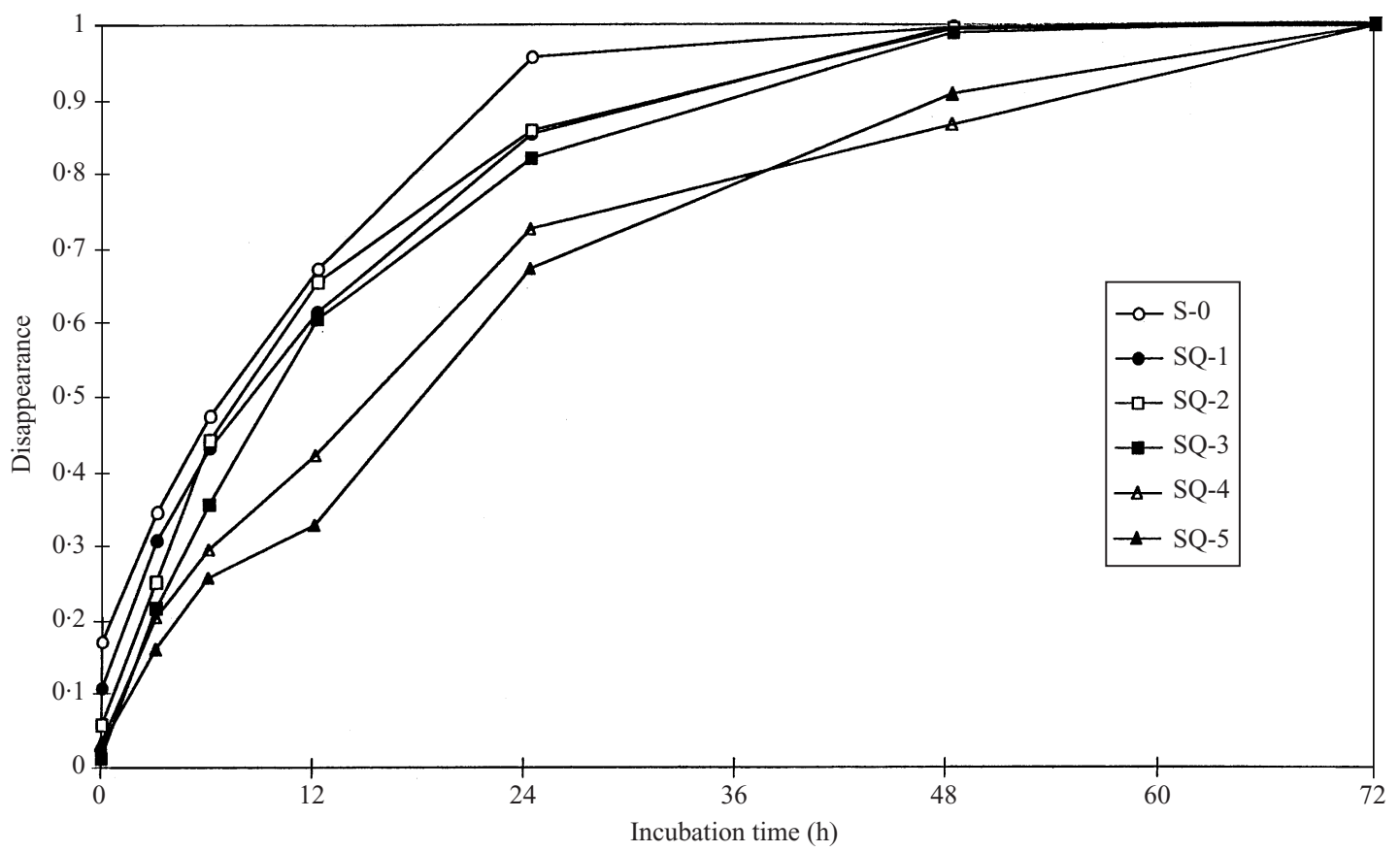

Fig. 2. In situ nitrogen disappearance curves of the control $\left(\mathrm{S}_{0}\right)$ and quebracho-treated soya bean meals $\left(\mathrm{S}_{\mathrm{Q} 1}, \mathrm{~S}_{\mathrm{Q} 2}, \mathrm{~S}_{\mathrm{Q} 3}, \mathrm{~S}_{\mathrm{Q} 4}\right.$ and $\mathrm{S}_{\mathrm{Q} 5}$ ). S.E. for the interaction between incubation time and quebracho tannin treatment $=0 \cdot 0263$ (D.F. $=70$ ). 
Table 1. Rumen degradation parameters $\left(a, b\right.$ and $c$ values) and degradability of the control $\left(S_{0}\right)$ and quebrachotreated soya bean meals $\left(S_{Q 1}, S_{Q 2}, S_{Q 3}, S_{Q 4}\right.$ and $\left.S_{Q 5}\right)$ dry matter $(D M)$ and nitrogen $(N)$

\begin{tabular}{|c|c|c|c|c|c|c|c|}
\hline & \multicolumn{7}{|c|}{ Soya bean meals } \\
\hline & $\mathrm{S}_{0}$ & $\mathrm{~S}_{\mathrm{Q} 1}$ & $\mathrm{~S}_{\mathrm{Q} 2}$ & $\mathrm{~S}_{\mathrm{Q} 3}$ & $\mathrm{~S}_{\mathrm{Q} 4}$ & $\mathrm{~S}_{\mathrm{Q5}}$ & $\begin{array}{c}\text { S.E. } \\
(\text { D.F. }=10)\end{array}$ \\
\hline \multicolumn{8}{|c|}{$a$ value (rapidly degradable fraction) } \\
\hline $\mathrm{DM}$ & $0 \cdot 305$ & 0.308 & $0 \cdot 300$ & $0 \cdot 277$ & $0 \cdot 292$ & $0 \cdot 293$ & 0.0076 \\
\hline $\mathrm{N}$ & $0 \cdot 154$ & $0 \cdot 132$ & $0 \cdot 055$ & $0 \cdot 041$ & $0 \cdot 048$ & 0.032 & 0.0069 \\
\hline \multicolumn{8}{|c|}{$b$ value (slowly degradable fraction) } \\
\hline DM & $0 \cdot 695$ & 0.692 & $0 \cdot 700$ & $0 \cdot 723$ & $0 \cdot 700$ & $0 \cdot 707$ & $0 \cdot 0090$ \\
\hline $\mathrm{N}$ & $0 \cdot 845$ & 0.867 & $0 \cdot 945$ & $0 \cdot 957$ & $0 \cdot 942$ & 0.968 & 0.0099 \\
\hline \multicolumn{8}{|c|}{$c$ value (rate of degradation) } \\
\hline DM & $0 \cdot 082$ & 0.072 & $0 \cdot 081$ & $0 \cdot 075$ & $0 \cdot 042$ & $0 \cdot 046$ & $0 \cdot 0082$ \\
\hline $\mathrm{N}$ & $0 \cdot 087$ & 0.072 & $0 \cdot 085$ & $0 \cdot 070$ & $0 \cdot 051$ & $0 \cdot 046$ & $0 \cdot 0089$ \\
\hline \multicolumn{8}{|c|}{ Degradability } \\
\hline DM & 0.657 & 0.634 & 0.648 & $0 \cdot 625$ & 0.531 & 0.549 & 0.0192 \\
\hline $\mathrm{N}$ & $0 \cdot 592$ & 0.542 & $0 \cdot 534$ & $0 \cdot 487$ & $0 \cdot 411$ & $0 \cdot 386$ & 0.0249 \\
\hline
\end{tabular}

Table 2. In situ dry matter $(D M)$ and nitrogen $(N)$ disappearance in 'control' and 'dosed' (receiving $0 \cdot 75 \mathrm{~g}$ of quebracho tannin powder $/ \mathrm{kg} L \mathrm{~W} /$ day) ewes, of the control $\left(S_{0}\right)$ and quebracho-treated soya bean meal $\left(S_{Q 4}\right)$, after 30 or 60 days of dosing

\begin{tabular}{|c|c|c|c|c|c|c|c|c|c|}
\hline & \multicolumn{3}{|c|}{ Animal treatment } & \multicolumn{3}{|c|}{ SBM treatment } & \multicolumn{3}{|c|}{ Time } \\
\hline & Control & 'Infused' & $\begin{array}{c}\text { S.E. } \\
\text { (D.F. }=8)\end{array}$ & $\mathrm{S}_{0}$ & $\mathrm{~S}_{\mathrm{Q} 4}$ & $\begin{array}{c}\text { S.E. } \\
\text { (D.F. }=8)\end{array}$ & day 30 & day 60 & $\begin{array}{c}\text { S.E. } \\
\text { (D.F. }=16)\end{array}$ \\
\hline DM & 0.749 & 0.671 & 0.0193 & 0.738 & 0.681 & 0.0072 & $0 \cdot 718$ & $0 \cdot 701$ & $0 \cdot 0127$ \\
\hline $\mathrm{N}$ & $0 \cdot 680$ & $0 \cdot 601$ & 0.0238 & $0 \cdot 716$ & $0 \cdot 565$ & 0.0099 & 0.647 & $0 \cdot 634$ & $0 \cdot 0161$ \\
\hline
\end{tabular}

All interactions were non-significant $(P>0 \cdot 05)$.

decreased $(P<0.05)$ the intestinal digestion $(0.939$, $0.916,0.878,0.885,0.902$ and 0.826 for $\mathrm{S}_{0}, \mathrm{~S}_{\mathrm{Q} 1}, \mathrm{~S}_{\mathrm{Q} 2}$, $\mathrm{S}_{\mathrm{Q} 3}, \mathrm{~S}_{\mathrm{Q} 4}$ and $\mathrm{S}_{\mathrm{Q} 5}$, respectively. S.E. $=0 \cdot 0276$; D.F. $=6$ ).

\section{Ruminal dosing of quebracho}

Dry matter and nitrogen disappearances from the bags incubated for $12 \mathrm{~h}$ in the rumen of 'control' and quebracho dosed ewes are shown in Table 2. Results are presented as means of the main effects because no treatment interactions were found to be significant.

In line with results obtained in Experiment 1, quebracho-treated soya bean meal showed lower DM and $\mathrm{N}$ disappearances after $12 \mathrm{~h}$ incubations in the rumen $(P<0 \cdot 01)$.

Dosing of quebracho powder into the rumen of sheep decreased the ability of these 'dosed' animals to degrade soya bean meal dry matter and nitrogen, compared to the control group $(P<0 \cdot 01)$.

There was no evidence for changes caused by the quebracho dosing between 30 and 60 days of treatment. Thus, average values on days 30 or 60 of the experiment were not significantly different for either $\mathrm{DM}$ or $\mathrm{N}$ disappearances from the bags $(P>0 \cdot 05)$.
Animals remained healthy throughout the experimental period. No signs of intoxication by condensed tannins were found either at necropsy or following histological examination.

\section{DISCUSSION}

Since one of the key goals of ruminant protein nutrition is to optimize the efficiency of utilization of dietary $\mathrm{N}$, reducing the rate and extent of ruminal degradation of protein-rich feeds, the study of the $\mathrm{pH}$ dependent behaviour of condensed tannins has been suggested in order to use these compounds as chemical additives to reduce the ruminal degradation of feed proteins (Schwab 1995).

It must be noted, first of all, that commercial quebracho is in fact a complex mixture of condensed tannin and simple phenolics (Asquith \& Butler 1985). The content of condensed tannin in the quebracho powder used in these trials (Roy Wilson Dickson Ltd., England) was $760 \mathrm{~g} / \mathrm{kg}$. However, the strong affinity of the condensed tannin molecule for the peptide group, responsible for the possible reduction of the degradation of the dietary protein in the rumen, 
is not expected to occur with simple phenols and, for this reason, quebracho tannin has been widely used as a model of condensed tannins in this kind of trial (e.g. Makkar et al. 1995; Salawu et al. 1997) and results observed can be attributed to the effects of the CT.

According to the results found in this experiment, quebracho treatment may decrease ruminal degradation of soya bean meals without detrimentally affecting their intestinal digestion. In general, doses used to treat $\mathrm{S}_{\mathrm{Q} 1}, \mathrm{~S}_{\mathrm{Q} 2}$ and $\mathrm{S}_{\mathrm{Q} 3}$ were not high enough to show significant treatment effects. For $\mathrm{S}_{\mathrm{Q} 4}$ and $\mathrm{S}_{\mathrm{Q} 5}$, no significant difference was observed between them in relation to ruminal degradation. However, the reduction of the intestinal digestion of the SBM treated with the highest dose of quebracho $\left(\mathrm{S}_{\mathrm{Q} 5}\right)$ suggests that $15 \mathrm{~g} / 100 \mathrm{~g}$ of soya bean meal $(13 \mathrm{~g} \mathrm{Q} / 100 \mathrm{~g}$ of quebracho treated SBM) is sufficient to achieve the intended results.

The quebracho treatment significantly reduced the degradability of the soya bean meal. This effect was partially due to a reduction in the rapidly degradable fraction $(a)$ but mainly to a lower rate of degradation (c). These results are consistent with those obtained by Salawu et al. (1997) in sheep given a quebracho tannin-containing diet. Aharoni et al. (1998) also indicated that the suppressive effect of tannins on ruminal degradation was a result of both the specific inhibition of degradation (through a decrease in the kinetic parameter ' $c$ ') and of the free-material binding capacity of tannins.

Interference of condensed tannins with microbial attachment has been proposed as one of the reasons for their action in reducing degradability. Microbial attachment is essential for the development of the complex microbial population required for feed degradation in the rumen. In pure culture studies, CT readily form complexes with microbial enzymes, interfere with microbial attachment and consequently inhibit digestion by rumen bacteria (McAllister et al. 1994).

In general, the protective role of tannins against rumen degradation was more evident for $\mathrm{N}$ than for DM. Tannins have been found to have a greater affinity for protein than for other moieties, which has been attributed to the strong hydrogen bond affinity of the phenolic groups of the tannin molecule with the carbonyl oxygen of the peptide group (McLeod 1974).

Although it is recognized that in vitro studies may not be truly representative of biological systems, the results obtained from the three-step in vitro procedures described by Calsamiglia \& Stern (1995) permit some conclusions to be drawn on the effect of the quebracho treatment of the soya bean meal on the intestinal digestion of its non-degradable protein. It seems clear that while the quebracho treatment at the doses used to treat $\mathrm{S}_{\mathrm{Q} 1}, \mathrm{~S}_{\mathrm{Q} 2}, \mathrm{~S}_{\mathrm{Q} 3}$ and $\mathrm{S}_{\mathrm{Q} 4}$ did not significantly decrease the intestinal digestion, the highest dose used for $\mathrm{S}_{\mathrm{Q} 5}$ did. The lack of difference in the intestinal digestion between control and quebracho-treated soya bean meals (up to a dose of commercial quebracho of $130 \mathrm{~g} / \mathrm{kg}$ of treated SBM) might be compared with the findings of Barry \& Manley (1984), who reported that the lower ruminal degradation of condensed tannin-containing diets was almost entirely compensated for by the greater post-ruminal digestion. These results call into question the oft-quoted negative effects of condensed tannins on protein digestion. It has also been indicated that condensed tannins may induce a depressive effect on the intestinal activity of trypsin and amylase (Silanikove et al. 1994). Proteins bound by condensed tannins would probably be resistant to attack by proteases (Van Soest 1994). The overall effect of the quebracho tannins seems to be strongly dependent on the dose with low doses having a potential beneficial effect.

Results from the in situ studies carried out during the second trial, in control and quebracho dosed ewes, confirmed the ability of quebracho tannins to decrease ruminal degradation of the soya bean meal. $\mathrm{DM}$ and $\mathrm{N}$ disappearance values were, in all cases, higher than those found in the first experiment. There are at least two possible explanations for this. On the one hand, rumen degradation of the soya bean meal may be highly variable depending on the consignment. On the other hand, the basal diet was different in Experiments 1 and 2, which could have affected the physico-chemical conditions of the rumen environment and hence the ruminal activity (Giráldez et al. 1994).

Essentially, the second experiment was conducted to ensure that physiological adaptation to quebracho tannins does not reduce the effectiveness of quebracho treatment in protecting SBM from ruminal degradation. It had been previously reported that exposure to some secondary compounds such as, for example, oxalic acid, mimosine or hydrolysable tannins, may increase the tolerance of animals to those compounds through changes to the composition of their microbial population (Quirk et al. 1988; Skene \& Brooker 1995; Dominguez-Bello 1996; Duncan et al. 1997). Given the phenolic nature of the CT molecule and its similarity to lignin, it was unlikely that extensive microbial degradation would occur in the rumen. Nonetheless, one of the concerns about the use of quebracho as a chemical additive was the possibility of its degradation by ruminal micro-organisms adapted to condensed tannins and able to degrade them. In this case, in adapted animals, quebracho-treated feeds would be as vulnerable as non-treated feeds to rumen microbial fermentation, therefore presenting similar values of $\mathrm{DM}$ and $\mathrm{N}$ rumen degradation.

According to the results found in this experiment, however, long-term dosing of quebracho tannin into the rumen of sheep did not increase the ability of the rumen microbes to degrade tannin-treated SBM, which suggests that physiological adaptation would 
not increase their ability to degrade condensed tannins in response to the presence of these compounds in the rumen. It is important to point out, in any case, that CT degradation by rumen microbes is still an issue about which there is little understanding and further research is needed in this area.

Results from the present experiment suggest a lower microbial activity in the rumen of ewes dosed daily with quebracho, which could be due to alterations in rumen fermentation patterns. These alterations were manifest on day 30 and, according to values obtained on day 60 , the response of the rumen to the quebracho dosing did not change with time following changes elicited before the day 30 .

Concerning toxicity, acute tannic acid intoxication has often been reported in ruminants (Murdiati et al. 1990; Zhu \& Filippich 1992). However, to our knowledge, very few studies have demonstrated condensed tannin intoxication.

The lack of toxic signs found in this experiment agrees with observations made in goats by Silanikove et al. (1996), who reported that animals fed tannincontaining leaves did not exhibit toxic symptoms. Furthermore, it must be noted that the amount of quebracho tannins used as chemical additive to protect soya bean meal and ingested by the animal, under practical conditions, would be lower than that dosed in this experiment into the rumen of sheep.

In conclusion, the present experiment suggests the possibility of using quebracho to decrease ruminal degradation of soya bean meal without detrimentally affecting its intestinal digestion, as long as the dose used is not higher than $130 \mathrm{~g}$ of quebracho per $\mathrm{kg}$ of treated SBM. This supports the hypothesis that these polyphenols might be used as chemical additives for improving the digestive utilization of protein-rich feeds in sheep.

The authors wish to thank Dr V. Pérez from the University of León (Spain) for conducting the pathoanatomical study and Drs S. López (University of León, Spain) and A. J. Duncan (Macaulay Land Use Research Institute, Aberdeen, UK) for helpful comments and revision of the manuscript. This work was supported by the Inter-ministerial Commission of Science and Technology (CICYT) of Spain (Project AGF98-0874).

\section{REFERENCES}

AFRC (1993). Energy and Protein Requirements of Ruminants. An advisory manual prepared by the AFRC Technical Committee on responses to nutrients. Wallingford, UK: CAB International.

Aharoni, Y., Gilboa, N. \& Silanikove, N. (1998). Models of suppressive effect of tannins. Analysis of the suppressive effect of tannins on ruminal degradation by compartmental models. Animal Feed Science and Technology 71, 251-267.

Association of Official Agricultural Chemisits (AOAC) (1990). Official Methods of Analysis of the Association of Official Agricultural Chemists, 15th edn. Washington, DC: AOAC.

AsQuith, T. N. \& ButLer, L. G. (1985). Use of dye-labelled protein as spectrophotometric assay for protein precipitants such as tannin. Journal of Chemical Ecology 11, $1535-1544$.

BARRY, T. N. \& MANLEY, T. R. (1984). The role of condensed tannins in the nutritional value of Lotus pedunculatus for sheep. British Journal of Nutrition 51, 493-504.

Calsamiglia, S. \& Stern, M. D. (1995). A three-step in vitro procedure for estimating intestinal digestion of protein in ruminants. Journal of Animal Science 73, 1459-1465.

Cheeke, P. R. \& Palo, R. T. (1995). Plant toxins and mammalian herbivores: co-evolutionary relationships and antinutritional effects. In Recent Developments in the Nutrition of Herbivores (Eds M. Journet, E. Grenet, M.-H. Farce, M. Thériez \& C. Demarquilly), pp. 437-456. Proceedings of the IVth International Symposium on the Nutrition of Herbivores. Paris: INRA Editions.

Dominguez-Bello, M. G. (1996). Detoxification in the rumen. Annales de Zootechnie 45 (suppl.), 323-327.

Duncan, A. J., Frutos, P. \& Young, S. A. (1997). Rates of oxalic acid degradation in the rumen of sheep and goats in response to different levels of oxalic acid administration. Animal Science 65, 451-455.

Giráldez, F. J., Mantecón, A. R., Chaso, M. A. \& Manso, T. (1994). Efecto del tipo de dieta y de la frecuencia de alimentación sobre la actividad degradativa ruminal. Investigación Agraria. Producción y Sanidad Animales 9 , 245-259.

Goering, M. K. \& Van Soest, P. J. (1970). Forage fiber analysis (apparatus, reagents, procedures and some applications). Agriculture Handbook, No. 379. Washington, USA: Agricultural Research Service, USDA

GrifFITHS, D. W. (1979). The inhibition of digestive enzymes by extracts of field bean (Vicia faba). Journal of the Science of Food and Agriculture 30, 458-462.

Horigome, T., Kumar, R. \& Oкамото, K. (1988). Effects of condensed tannins prepared from leaves of fodder plants on digestive enzymes in vitro and in the intestine of rats. British Journal of Nutrition 60, 275-285.

Makkar, H. P. S., Becker, K., Abel, H. \& Szegletti, C. (1995). Degradation of condensed tannins by rumen microbes exposed to quebracho tannins (QT) in rumen simulation technique (RUSITEC) and effects of QT on fermentative processes in the RUSITEC. Journal of the Science of Food and Agriculture 69, 495-500.

McAllister, T. A., Bae, H. D., Jones, G. A \& Cheng, K.J. (1994). Microbial attachment and feed digestion in the rumen. Journal of Animal Science 72, 3004-3018.

MCLeOD, M. N. (1974). Plant tannins. Their role in forage quality. Nutrition Abstracts and Reviews 44, 803-815.

Murdiati, T. B., McSweeney, C. S., Campbell, R. S. F. \& Stoltz, D. S. (1990). Prevention of hydrolisable tannin toxicity in goats fed Clidemia hirta by calcium hydroxide supplementation. Journal of Applied Toxicology 10, 325-331. 
ØRskov, E. R. \& McDonald, I. (1979). The estimation of protein degradability in the rumen from incubation measurements weighed according to the rate of passage. Journal of Agricultural Science, Cambridge 92, 499-503.

Perez-Maldonado, R. A. \& Norton, B. W. (1996). Digestion of ${ }^{14} \mathrm{C}$-labelled condensed tannins from Desmodium intortum in sheep and goats. British Journal of Nutrition 76, 501-513.

Quirk, M. F., Bushell, J. J., Jones, R. J., Megarrity, R. G. \& Butler, K. L. (1988). Live-weight gains on leucaena and native grass pastures after dosing cattle with rumen bacteria capable of degrading DHP, a ruminal metabolite from leucaena. Journal of Agricultural Science, Cambridge 111, 165-170.

Salawu, M. B., Acamovic, T. Stewart, C. S., Hovell, F. D. DeB. \& MCKAy, I. (1997) Assessment of the nutritive value of Calliandra calothyrus: in sacco degradation and in vitro gas production in the presence of quebracho tannins with or without Browse plus. Animal Feed Science and Technology 69, 219-232.

SAS (1989). SAS/STAT ${ }^{\circledR}$ User's Guide Int. (Version 6, 4th Edn). SAS Institute Inc., Cary, NC.

Schwab, C. G. (1995). Protected proteins and amino acids for ruminants. In Biotechnology in Animals Feeds and Animal Feeding (Eds R. J. Wallace \& A. Chesson), pp. 115-141. Weinheim, Germany: V. C. H. Press.

Silanikove, N., Gilboa, N., Perevolotsky, A \& Nitsan, Z. (1996). Goats fed tannin-containing leaves do not exhibit toxic syndromes. Small Ruminant Research 21, 195-201.

Silanikove, N., Nitsan, Z. \& Perevolotsky, A. (1994). Effect of a daily supplementation of polyethylene glycol on intake and digestion of tannin-containing leaves (Ceratonia siliqua) by sheep. Journal of Agricultural and Food Chemistry 42, 2844-2847.

Skene, I. K. \& Brooker, J. D. (1995). Characterization of tannin acylhydrolase activity in the ruminal bacterium Selenomonas ruminantium. Anaerobe 1, 321-327.

Terrill, T. H., Waghorn, D. J., Wooley, D. J., McNabb, W. C. \& BARry, T. N. (1994). Assay and digestion of ${ }^{14}$ Clabelled condensed tannins in the gastrointestinal tract of sheep. British Journal of Nutrition 72, 467-477.

VAN SOEST, P. J. (1994). Plant defensive chemicals. In Nutrition Ecology of the Ruminant, 2nd Edn, pp. 196-221. Ithaca, New York: Cornell University Press

Zhu, J. \& FilipPICH, L. J. (1992). Tannic acid intoxication in sheep and mice. Research in Veterinary Science 53, 280-292. 